\title{
CLIMATE CHANGE AND RURAL WORKERS THERMAL COMFORT: HISTORICAL AND FUTURE IMPACTS
}

\author{
André L. N. Amaro ${ }^{1}$, Taday uki Yanagi Junior ${ }^{2 *}$, Sílvia de N. M. Yanagi ${ }^{1}$, Gabriel A. E S. Ferraz ${ }^{1}$, \\ Alessandro T. Campos ${ }^{1}$
}

${ }^{2 *}$ Corres ponding author. Universidade Federal de Lavras/ Lavras - MG, Brasil. E-mail: yanagi@deg.ufla.br

\section{KEYWORDS}

human

biometeorology,

human thermal

comfort, THI, time

series

\begin{abstract}
The aim of the present research was to propose a bioclimatic mapping to classify the thermal comfort and discomfort of rural workers within the state of Minas Gerais, considering historical and future scenarios. Monthly historical series (1976-2014) of minimum, mean and maximum temperature-humidity index (THI), determined through the values of air temperature (minimum, mean and maximum) and re lative humidity from 48 weather stations located in the state of Minas Gerais were used to analyze the trends through Mann-Kendall and linear regression assays. The bioclimatic mapping of human comfort, obtained via geostatistical analysis, was developed as a function of the minimum, medium and maximum THI for the historical period (1976-2014) and future scenario (2024). Results indicate an overall trend of increasing in thermal discomfort conditions throughout the mesoregions of the state of Minas Gerais during the weather seasons, being more incisive in summer and spring.
\end{abstract}

\section{INTRODUCTION}

Climate change can generate negative impacts on human beings, especially workers in some agribusiness activities that require higher metabolic activity. Impacts of the thermal environment on humans have been widely studied because of the harmful effects on performance and health (Ou et al., 2014) and, under extreme conditions, leading to death (Loughnan et al., 2010).

Under heat stress conditions, humans present changes in physiological parameters, such as increases in heart rate, body temperature, blood pressure, and sweat production (Shen \& Zhu, 2015). Heat-related disorders such as sunstroke, cramps and exhaustion have also been reported (Zheng et al., 2012). Extreme conditions of cold stress also cause health problems (McMichael et al., 2006).

Indexes of the thermal environ ment have been used to generate bioclimatic maps applied to the analysis of the effect of the external environment on humans (Park et al., 2014). A mong the various indexes, the temperature and humidity index (THI) (Thom, 1959) has been widely used to classify the level of thermal comfort of humans, in view of the easy obtaining of meteorological data used as input into the equation.

In this context, the goal of the present study was to propose a bioclimatic zoning to classify the thermal comfort and discomfort of rural workers in the State of Minas Gerais, using the temperature and humidity index (THI), considering a historical period and a future scenario.

\section{MATERIAL AND METHODS}

For the development of bioclimatic zoning of human comfort for the State of Minas Gerais, it was used data from 48 weather stations located in the State of Minas Gerais belonging to the National Institute of Meteorology (INMET) (Figure 1). The database is composed of the monthly average values of minimum, medium and maximu $m$ dry-bulb temperatures $\left(t_{d b, \text { min }}, t_{d b \text {, mean }}\right.$ and $t_{d b, \max }$, respectively) and air relative humidity $(\mathrm{RH})$.

\footnotetext{
${ }^{1}$ Universidade Federal de Lavras/ Lavras - MG, Brasil.

Received in: 8-25-2017

Accepted in: 11-20-2017
} 


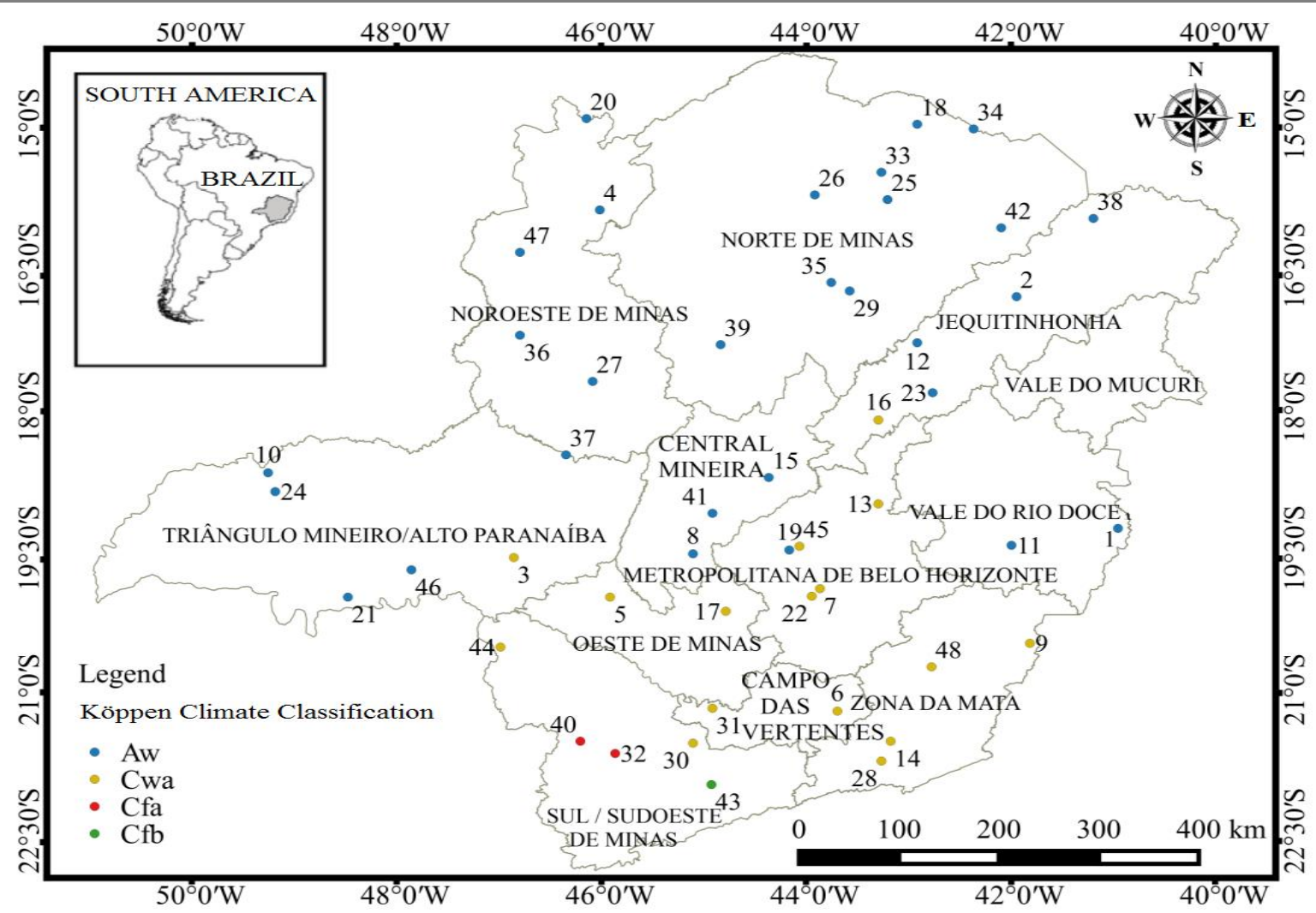

FIGURE 1. Location of the weather stations used in the present study.

The State of Minas Gerais has an area of approximately $7 \%$ of the Brazilian territory, with 582,586 $\mathrm{km}^{2}$ and wide climatic variability (Tonietto et al., 2006). The average values of annual precipitation vary from 700 to $1,100 \mathrm{~mm}$ in the driest regions (north, northeast and east) and from 1,200 to $1,500 \mathrm{~mm}$ in the rainier regions (South, Triângulo Mineiro, northwest and Serra do Espinhaço and Mantiqueira) (Mello \& Viola, 2013). In the lower regions of north and east of the State, the monthly average temperatures reach $27^{\circ} \mathrm{C}$, while in the higher regions are observed temperatures around $13^{\circ} \mathrm{C}$.

The weather stations used in this study are listed in Table 1, and the historical series of $t_{d b, \text { min }}, t_{d b \text {,mean }}, t_{d b, \text { max }}$ and $\mathrm{RH}$ were of 39 years, covering the period from 1976 to 2014.

TABLE 1. Conventional weather stations and their respective elevation.

\begin{tabular}{|c|c|c|c|c|c|c|c|c|}
\hline $\mathrm{N}^{\circ}$ & Station & $\begin{array}{c}\text { Elev. } \\
\text { (m) }\end{array}$ & $\mathrm{N}^{\circ}$ & Station & $\begin{array}{c}\text { Elev. } \\
(\mathrm{m})\end{array}$ & $\mathrm{N}^{\circ}$ & Station & $\begin{array}{c}\text { Elev. } \\
(\mathrm{m})\end{array}$ \\
\hline 1 & Aimorés & 83 & 17 & Div inópolis & 788.35 & 33 & Mocambinho & 452 \\
\hline 2 & Araçuaí & 289 & 18 & Espinosa & 596.64 & 34 & Monte Azul & 625 \\
\hline 3 & Ara xá & 1.024 & 19 & Florestal & 749 & 35 & Montes Claros & 652 \\
\hline 4 & Arinos & 519 & 20 & Formoso & 840 & 36 & Paracatu & 712 \\
\hline 5 & Bambuí & 661 & 21 & Frutal & 544 & 37 & Patos de Minas & 940 \\
\hline 6 & Barbacena & 1.126 & 22 & Ibirité & 815 & 38 & Pedra Azul & 648.91 \\
\hline 7 & Belo Horizonte & 915 & 23 & Itamarandiba & 1.097 & 39 & Pirapora & 505 \\
\hline 8 & Bom Despacho & 695 & 24 & Ituiutaba & 560 & 40 & Poços de caldas & 1.15 \\
\hline 9 & Caparaó & 843 & 25 & Janaúba & 516 & 41 & Pompéu & 691 \\
\hline 10 & Capinópolis & 620.6 & 26 & Januária & 474 & 42 & Salinas & 471 \\
\hline 11 & Caratinga & 610 & 27 & João Pinheiro & 760.36 & 43 & São Lourenço & 953 \\
\hline 12 & Carbonita & 736 & 28 & Juiz de Fora & 940 & 44 & São S. do Paraiso & 820 \\
\hline 13 & C do Mato Dentro & 652 & 29 & Juramento & 648 & 45 & Sete Lagoas & 732 \\
\hline 14 & Coronel Pacheco & 435 & 30 & Lambari & 878 & 46 & Uberaba & 737 \\
\hline 15 & Curvelo & 672 & 31 & Lavras & 919 & 47 & Unaí & 460 \\
\hline 16 & Diamantina & 1.296 & 32 & Machado & 873 & 48 & Viçosa & 712 \\
\hline
\end{tabular}

$\mathrm{N}$ - number of the weather station; Elev - station elevation 
THI was calculated through the (Equation 1) (Thom, 1958), based on $t_{d b, \text { min }}, t_{d b \text {,mean }}, t_{d b, \text { max }}\left({ }^{\circ} \mathrm{C}\right)$ and dew point temperature $\left(\mathrm{t}_{\mathrm{dp}}\right)$, that was determined by (Equation 2) (Vianello \& Alves, 2012) as a function of the actual water vapor pressure $(\mathrm{e}, \mathrm{hPa})$.

$$
\mathrm{THI}=\mathrm{t}_{\mathrm{db}}+0,36 \cdot \mathrm{t}_{\mathrm{dp}}+41,5
$$

where,

THI - temperature and humidity index (THI, dimensionless);

$\mathrm{t}_{\mathrm{db}}$ - air dry-bulb temperature, ${ }^{\circ} \mathrm{C}$;

$\mathrm{t}_{\mathrm{dp}}-$ air dew-point temperature, ${ }^{\circ} \mathrm{C}$,

$t_{d p}=(186,4905-237,3 \log e) /(\log e-8,2859)$

where,

$\mathrm{e}-$ actual water vapor pres sure, $\mathrm{hPa}$.

\section{Historical series trend analysis}

The trends of the historical series of $\mathrm{THI}_{\min }$, $\mathrm{THI}_{\text {mean }}, \mathrm{THI}_{\max }$ over a period of 39 years, for each studied station, were verified using the non-parametric MannKendall test (Mann, 1945; Kendall, 1975) proposed by Sneyers (1975), and the linear regression analysis, methodologies commonly used (Minuzzi, 2010, Ávila et al., 2014, Tian et al., 2016).

The non-parametric Mann-Kendall test considers that, since there is stability of the time series (Hypothesis $\mathrm{H}_{0}$ ), the succession of values occurs independently and the probability distribution remains unchanged (simple random series).

A time series will present a tendency of increase or decrease of a certain variable if the value of the MannKendall coefficient is positive (MK>0) or negative (MK $<0$ ), respectively. For this purpose, the $\mathrm{Z}$ test should be applied at the $5 \%$ level of significance, which provides $\mathrm{Z}_{0.975}=1.96$. It is rejected $\mathrm{H}_{0}$ if the Mann-Kendall test, $|\mathrm{MK}|>\mathrm{Z} 1_{-\alpha / 2}$, is greater than 1.96 , indicating a significant trend in the data time series (AVILA et al., 2014). The S statistic was determined by (Equation 3), where $\mathrm{n}$ is the number of observations, $\mathrm{Xj}$ and $\mathrm{Xi}$ are the sequential values of the data and $\operatorname{sgn}(\phi)$ is the signal function. The signal function assumes a value of 1 if $\phi>0 ; 0$ if $\phi=0$; and -1 if $\phi<0$.

$$
\mathbf{S}=\sum_{\mathrm{i}=1}^{\mathrm{n}-1} \sum_{\mathrm{j}=\mathrm{i}+1}^{\mathrm{n}} \operatorname{sgn}\left(\mathrm{X}_{\mathrm{j}}-\mathrm{X}_{\mathrm{i}}\right)
$$

According to Kendall (1975), assuming the hypothesis that the data are identically distributed and independent, the average and the variance of the $\mathrm{Z}$ statistic are given by (Equations 4 and 5), respectively. The $\mathrm{m}$ is the number of associated classification groups, each one associated with a ti, which corresponds to the THI values of the historical series of $\mathrm{THI}_{\min }, \mathrm{THI}_{\text {mean }}$ and $\mathrm{THI}_{\max }$.

$$
\mathrm{E}(\mathrm{S})=\mathbf{0}
$$

$\operatorname{Var}(S)=\frac{\mathrm{n} \cdot(\mathrm{n}-1) \cdot(2 \cdot \mathrm{n}+5)-\sum_{1=1}^{\mathrm{m}} \mathrm{ti} \cdot(\mathrm{ti}-1) \cdot(2 \cdot \mathrm{ti}+5)}{18}$

The value of $\mathrm{Z}$ can be calculated as follows:

$$
Z= \begin{cases}\frac{s-1}{\sqrt{\operatorname{Var}(s)},} & \text { if } S>0 \\ 0, & \text { if } S=0 \\ \frac{s+1}{\sqrt{\operatorname{Var}(s)}}, & \text { if } S<0\end{cases}
$$

The linear regression analys is was applied to obtain trends through the parametric significance $t$ test over the angular coefficient ( $\beta$ ) (Longobardi \& Villani, 2010). This test considered the linear regression between the random variable $\mathrm{Y}$ (THI series) and time (X). The trend for a period of 10 years (2024) was calculated using the adjusted linear equations, multip lying $\beta$ by 10 .

\section{Bioclimatic zoning}

The bioclimatic zoning was carried out through the interval maps of $\mathrm{THI}_{\min }$, $\mathrm{THI}_{\text {mean }}$ and $\mathrm{THI}_{\max }$ for the State of Minas Gerais, considering the historical period from 1976 to 2014, and indicating trends for 2024, a decade after the end of the data historical series.

Statistical analysis and linear regression were performed by the $\mathrm{R}$ program ( $\mathrm{R}$ Development Core Team, 2014). The creation of the maps was made by the ArcGIS for Desktop 10.4 program, through its extensions, Spatial Analyst and Geostatistical Analyst. The spatial dependence of the THI in the State of Minas Gerais was analyzed by means of the semivariogram adjustment using the OLS method, adjusting the spherical model, and the interpolation was carried out using ordinary kriging (Ferraz et al., 2015).

The zones of thermal comfort and discomfort for rural workers were defined considering that the rural workers exert moderate activities, with metabolic rate of $175 \mathrm{~W}$, working stand-up, with movement of arms and legs and the use of light clothes, that is, with thermal resistance of $0.09^{\circ} \mathrm{C} \mathrm{W} \mathrm{m}^{-2}$ (Oliveira et al., 2006).

The thermal environments were classified as comfort (THI $<74)$, hot $(74 \leq \mathrm{THI}<79)$, very hot $(79 \leq \mathrm{THI}<84)$ and extremely hot $(\mathrm{THI} \geq 84)$ (Lamberts et al., 1997; Oliveira et al., 2006). Thermal discomfort begins in the hot environment and can cause health problems and reduce rural workers' performance. The very hot environment indicates danger and can cause serious effects to health and the extremely hot environment can cause very serious health risks.

\section{RES ULTS AND DISCUSS ION}

The spatial distribution of the average historical values (1976-2014) of $\mathrm{THI}_{\min }$ and $\mathrm{THI}_{\text {mean }}$ indicate that the thermal environment in almost all seasons was classified as a comfort situation (THI <74), except for spring. At this season, the $\mathrm{THI}_{\text {mean }}$ in some parts of the mesoregion of the Triângulo Mineiro/Alto Paranaíba and part of the boarder of the mesoregions of the Northwest and North of Minas Gerais presented values in the interval between 74 and 79 , characterizing the region as hot (Figure 2). 
A.

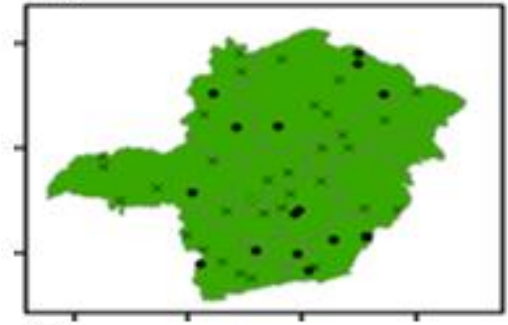

D.

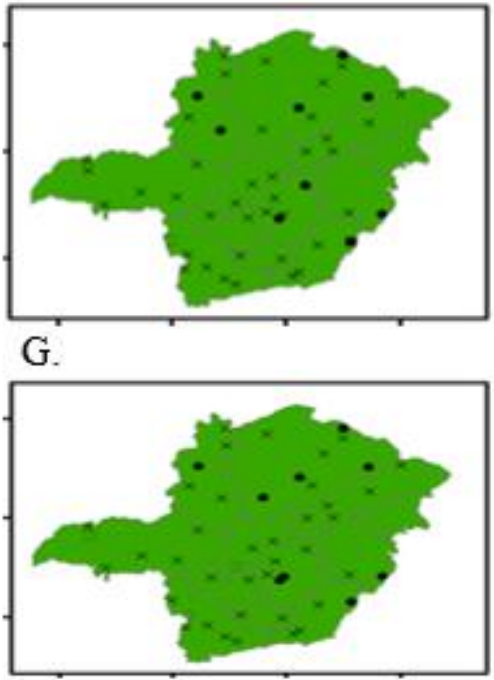

J.

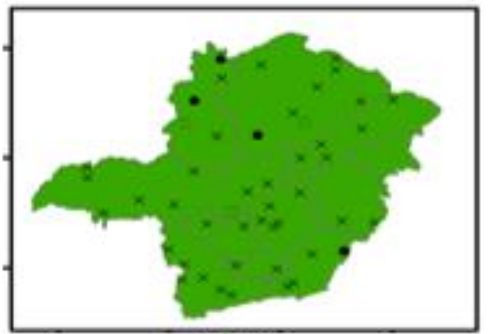

THI
B.

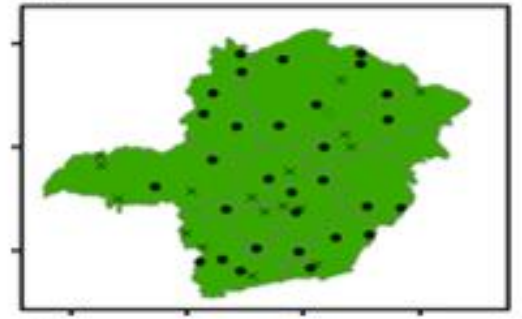

E.

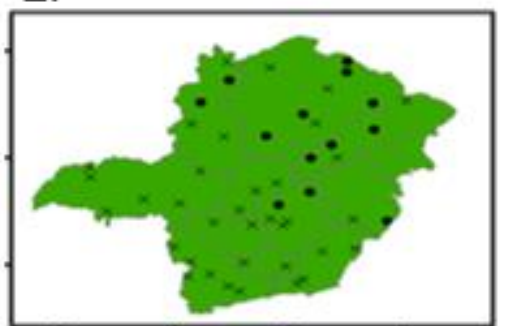

$\mathrm{H}$.

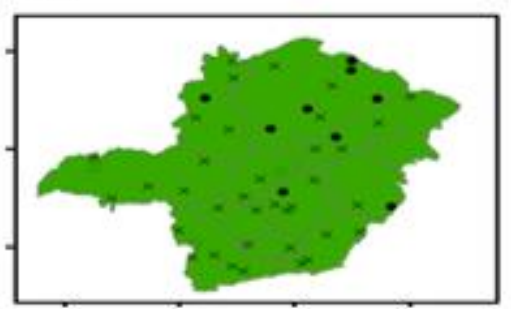

$\mathrm{K}$.

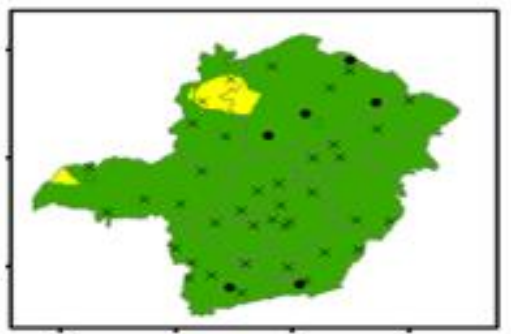

C.

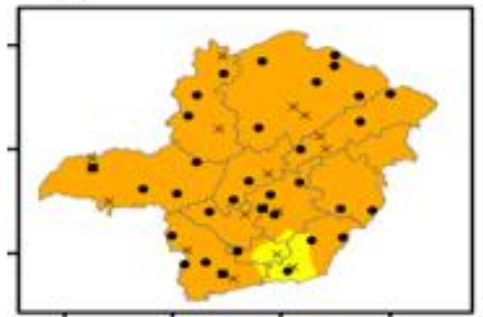

F.

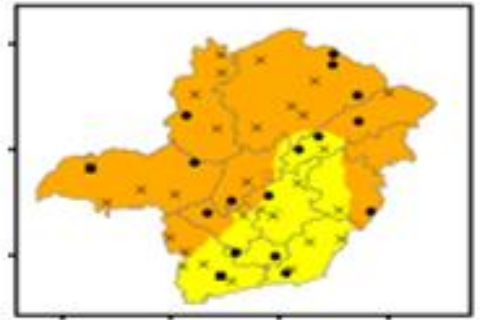

I.

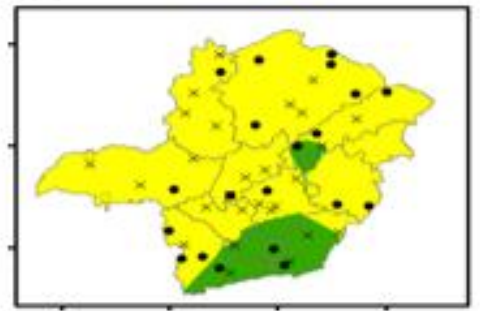

L.

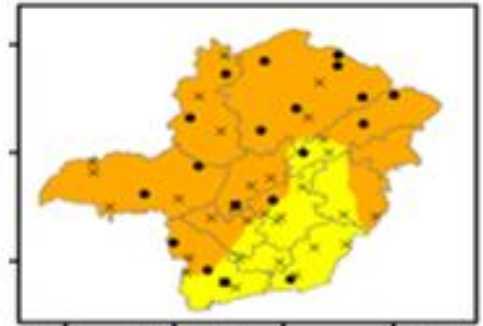

Trend for 10 years (2024)

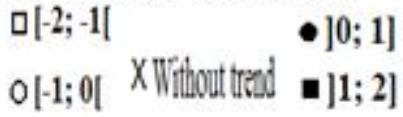

FIGURE 2. Variation of the minimum, medium and maximum temperature and humidity index (THI) (summer: (A), (B) and (C), respectively; fall: (D), (E) and (F), respectively; winter: (G), (H) and (I), respectively; spring: (J), (K) and (L), respectively), for the period from 1976 to 2014, in the evaluated municipalities of the State of Minas Gerais, and their THI trends for a decade (2024).

In relation to the average historical values of $\mathrm{THI}_{\max }$, it can be observed that only during the winter period (Figure 2I), part of the mesoregions of South/Southwest of Minas Gerais, Campos das Vertentes, Zona da Mata, West of Minas Gerais and Belo Horizonte Region, Jequitinhonha and Vale do Rio Doce presented comfort conditions (THI <74). The other mesoregions were classified as hot $(74 \leq \mathrm{THI}<79)$ or very hot $(79 \leq$ THI <84) for winter and other seasons. The very hot areas have expanded throughout the seasons, from winter to summer and declining in fall (Figures 2C, 2F, 2I, 2L); similar to what was observed by Oliveira et al. (2006).

Thus, periods with thermal conditions classified as hot $(74 \leq \mathrm{THI}<79)$ and very hot $(79<\mathrm{THI} \leq 84)$ were observed at all seasons in the State of Minas Gerais for $\mathrm{THI}_{\max }$, corroborating with Oliveira et al. (2006). Therefore, minor or serious health problems, in addition to the reduction in the performance of rural workers are expected. It is emphasized that, hourly variations of the THI can cause situations of thermal discomfort (Buriol et al., 2015), intensifying the discomfort.

The comfort classification verified for $\mathrm{THI}_{\text {mín }}$ in the four seasons in the historical period (1976-2014) did not change in 2024 (Figure 3), although tendencies of increase and reduction of these values were observed (Figures 2A, 2D, 2G, 2J).

The reductions in the occurrence frequency of the condition classified as comfort for the $\mathrm{THI}_{\text {mean }}$ in the 
summer, fall, winter and spring seasons were $6.25 \%$, $0.00 \%, 0.00 \%$ and $2.08 \%$, respectively. These percentages of reduction were consequently added to the condition of the thermal environment classified as hot (Figure 3). Reduction on $6.25 \%$ of the situation classified as hot and increase of very hot situation was verified for $\mathrm{THI}_{\max }$ (Figure 3A) in the summer season.
In the fall, it was observed the decrease of occurrences of $\mathrm{THI}_{\max }$ values for comfort conditions of 2.09 (Figure 3B). Consequently, it was observed a $2.09 \%$ increase in the extremely hot classification for $\mathrm{THI}_{\max }$ when comparing the 2024 scenario with the historical period (1979-2014).
A.

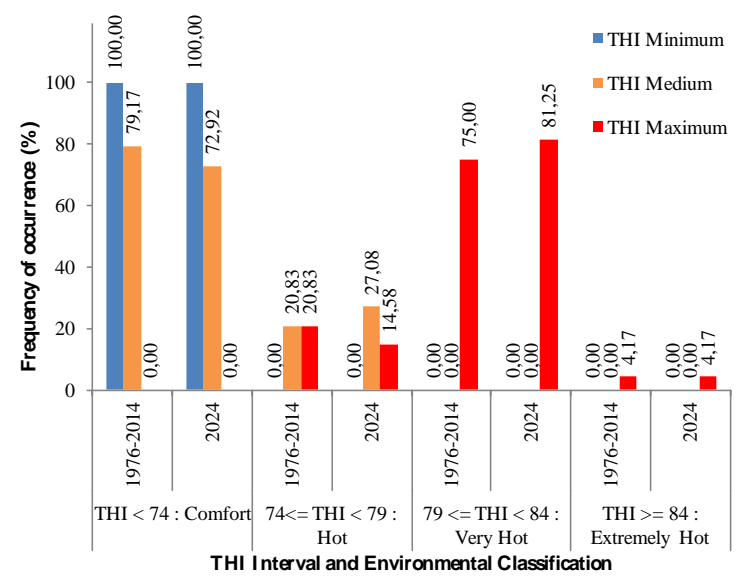

C.

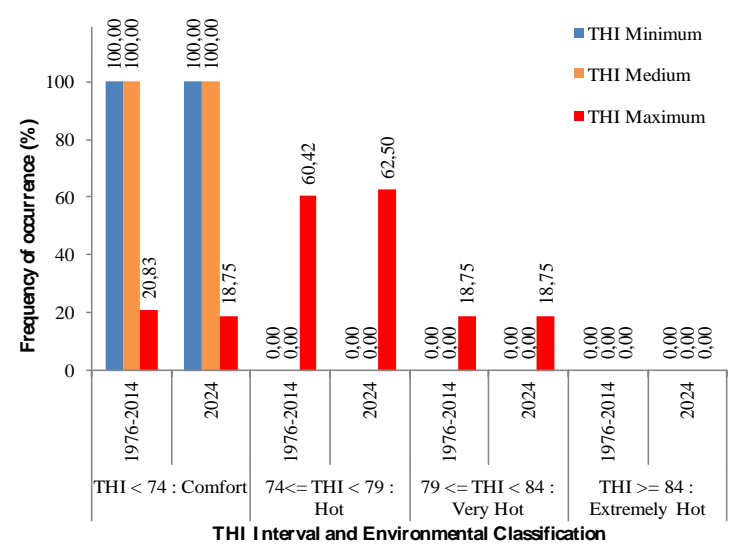

B.

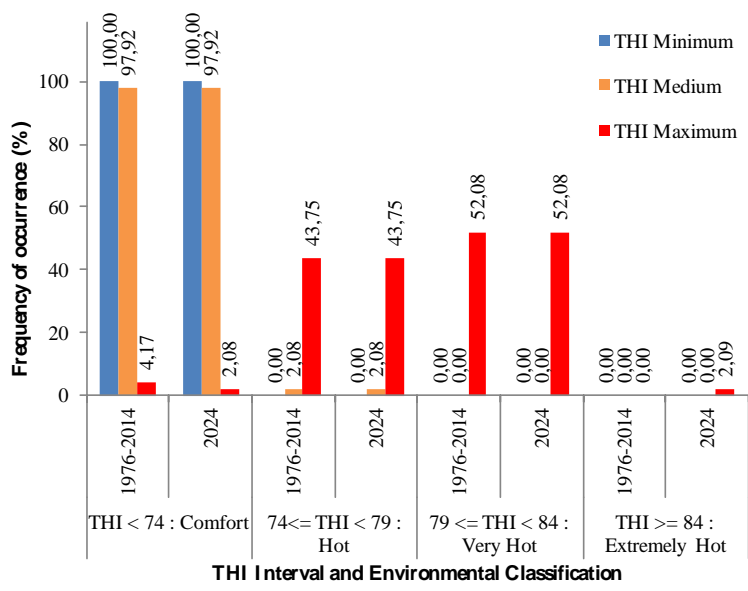

D.

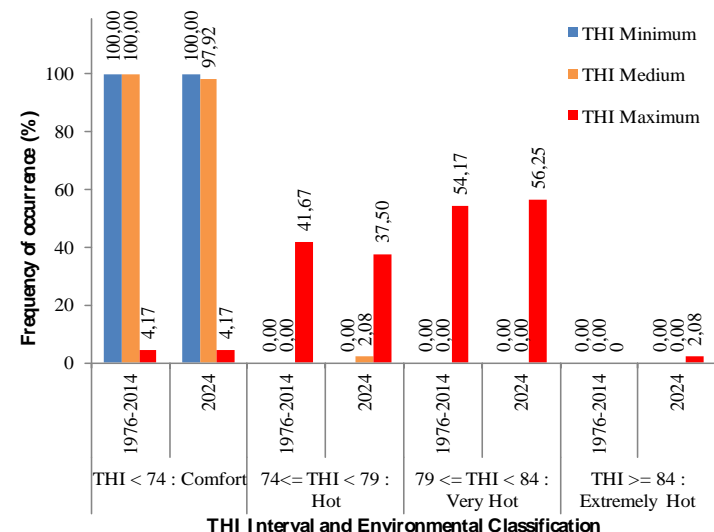

FIGURE 3. Variation of the occurrence frequency of $\mathrm{THI}_{\min }, \mathrm{THI}_{\mathrm{med}}$ and $\mathrm{THI}_{\max }$ in the seasons of (A) summer, (B) fall, (C) winter and (D) spring, for the period from 1976 to 2014 and for the year 2024, in the evaluated municipalities of the state of Minas Gerais

The trend analysis indicates, in general, the increase of the occurrence frequency of the hot classification in summer and spring for $\mathrm{THI}_{\text {mean }}$ and $\mathrm{THI}_{\max }$, when comparing the 2024 scenario with the historical period (1979-2014). So, it was verified the increase of the extre mely hot condition in autumn and spring. This profile due to climatic changes increases human discomfort especially in summer, fall and spring, in which the sums of $\mathrm{THI}_{\max }$ occurrences classified as very hot and extremely hot are $85.42 \%, 54.16 \%$ and $58.33 \%$, (Figure 3), respectively. The increase in human discomfort due to climate change was also verified by Potchter \& BenShalom (2013).

Zhang et al. (2014) recommended the upper limits of $\mathrm{t}_{\mathrm{db}}$ and $\mathrm{RH}$ of $29.2^{\circ} \mathrm{C}$ and $50 \%$ (THI $=77.1$ ) and $28.0^{\circ} \mathrm{C}$ and $70 \%$ (THI $=77.4$ ) so that $90 \%$ of people can be satisfied in circulation spaces in a hot and humid area of China. The satisfaction level of $73 \%$ was obtained for $t_{d b}$ and $\mathrm{RH}$ of $31.0^{\circ} \mathrm{C}$ and $50 \%(\mathrm{THI}=79.5)$ and of $29.5^{\circ} \mathrm{C}$ and $70 \%(\mathrm{THI}=79.4)$.

Changes in the thermal environment are related to declining work capacity (Dunne et al., 2013) and to the increased incidence of cardiovascular diseases (Ezekowitz et al., 2013) and mental disorders (Vaneckova \& Bambrick, 2013). The absence of actions to mitigate the thermal environment on humans can cause reduction of performance and increase of diseases, a situation that can be aggravated by climate changes.

Given the current climatic conditions and trends to the future, strategies to mitigate the thermal effects of the environment on humans must be analyzed, such as the selection of surrounding vegetation (Lee et al., 2016), materials selection (Ragheb et al., 2016), the energy demand for heating or cooling (Van Hove et al., 2015), the design of the building, among others. This knowledge is essential for studies related to the reduction and adaptation to climate change (Hjort et al., 2016). 


\section{CONCLUSIONS}

The bioclimatic zoning of the temperature and humidity index (THI) for the State of Minas Gerais indicated the occurrence of hot conditions $(74 \leq \mathrm{THI}<79)$ when analyzing the $\mathrm{THI}_{\text {mean }}$ in the summer and fall and very hot conditions $(79<\mathrm{THI} \leq 84)$ and extremely hot conditions (THI>84) for $\mathrm{THI}_{\max }$ throughout the year, except in the winter.

Trend analysis applied to the time series indicates worst conditions in 2024.

\section{ACKNOWLEDGEMENTS}

To the Federal University of Lavras (UFLA), FAPEMIG, CAPES and CNPq for financial support.

\section{REFERENCES}

Ávila LF, Mello CR, Yanagi SNM, Neto OBS (2014) Tendências de temperaturas mínimas e máximas do ar no Estado de Minas Gerais. Pesquisa Agropecuária Brasileira 49(4):247-256. DOI: 10.1590/S0100-204X2014000400002

Buriol GA, Estefanel V, Righi EZ, Bressan VC (2015) Conforto térmico para os seres humanos nas condições de amb iente natural em Santa Maria, RS, Brasil. Ciência Rural 45(2):223-230. DOI: http://d x.doi.org/10.1590/0103$8478 \mathrm{cr} 20131537$

Dunne JP, Stouffer RJ, Hohn JG (2013) Reductions in labour capacity from heat stress under climate warming. Nature Climate Change 3(6):563-566. DOI: http://dx.doi.org/10.1038/nclimate1827

Ezekowitz JA, Bakal JA, Westerhout CM, Giugliano RP, White H, Keltai M, Prabhakaran D, Tricoci P, Werf FV, Califf RM, Newby LK, Armstrong PW (2013) The relationship between meteorological conditions and index acute coronary events in a global clinical trial. International Journal of Cardiology 168(3):2315-2321. DOI: https://doi.org/10.1016/j.ijcard.2013.01.061

Ferraz GAS, Silva FM, Oliveira MS, Avelar RC, Sales RS (2015) Variabilidade es pacial da dose de P2O5 e K2O para adubação diferenciada e convencional em lavoura cafeeira. Coffee Science 10(3):346-356.

Hjort J, Suomi J, Käyhko J (2016) Extre me urban-rural temperatures in the coastal city of Turku, Fin land: Quantification and visualization based on a generalized additive model. Science of the Total Environment 569(1)507-517. DOI:

https://doi.org/10.1016/j.scitotenv.2016.06.136

Kendall MG (1975) Rank correlation methods. London, Charles Griffin. 210p.

Lamberts R, Dutra L, Pereira FOR (1997) Eficiência energética na arquitetura. São Pau lo, PW. 192p.

Lee H, Mayer H, Chen L (2016) Contribution of trees and grasslands to the mitigation of hu man heat stress in a residential district of Freiburg, Southwest Germany. Landscape and Urban Planning 148(1)37-50. DOI: https://doi.org/10.1016/j.landurbplan.2015.12.004

Longobardi A, Villani P (2010) Trend analysis of annual and seasonal rainfall time series in the Mediterranean area. International Journal of Climatology 30(10):1538-1546. DOI: https://doi.org/10.1002/joc. 2001
Loughnan M, Nicholls N, Tapper N (2010) Mortalitytemperature thresholds for ten major population centres in rural Victoria, Australia. Health \& Place 16(6):1287-1290. DOI: https://doi.org/10.1016/j.healthplace.2010.08.008

Mann H B (1945) Nonparametric test against trend. Economectrika 13(1):245-259. DOI: 10.2307/1907187

McMichael AJ, Woodruff RE, Hales S (2006) Climate change and human health: present and future risks. The Lancet 367(9513):859-869. DOI: https://doi.org/10.1016/S0140-6736(06)68079-3

Mello CR, Viola MR (2013) Mapeamento de chuvas intensas no estado de Minas Gerais. Revista Brasileira de Ciência do Solo 37(1):37- 44. Available in: http://www.redalyc.org/articulo.oa?id=180225736009

Minuzzi RB (2010) Tendências na variabilidade climática de Santa Catarina, Brasil. Revista Brasileira de Engenharia Agrícola e A mbiental 14(12):1288-1293. DOI: http://dx.doi.org/10.1590/S 1415-43662010001200006

Oliveira LMF, Yanagi junior T, Ferre ira E, Carvalho LG, Silva MP (2006) Zoneamento bioclimático da região Sudeste do Brasil para o conforto térmico animal e humano. Engenharia Agrícola 26(3)823-831.

Ou CQ, J YANG, Ou QQ, Liu HZ, Lin GZ, Chen PY, Qian J, Guo YM (2014) The impact of relative humidity and atmospheric pressure on mortality in Guangzhou, China. Biomedical and Environmental Sciences 27(12):917-925. DOI: https://doi.org/10.3967/bes 2014.132

Park S, Tuller SE, Jo M (2014) Application of Universal Thermal Climate Index (UTCI) for microclimatic analys is in urban thermal environ ments. Landscape and Urban Planning 125(1):146-155. DOI:

https://doi.org/10.1016/j.landurbplan.2014.02.014

Potchter O, Ben-Shalom HI (2013) Urban warming and global warming: Combined effect on thermal discomfort in the desert city of Beer Sheva, Israel. Journal of Arid Environments 98(1):113-122. DOI:

https ://doi.org/10.1016/j.jaridenv.2013.08.006

R Development Core Team. R: a language and environment for statistical computing. Vienna: R Foundation for Statistical Computing 2017. Available in: http://www.R-project.org/. Accessed: Jun 22, 2017.

Ragheb AA, El-darwish II, Ahmed S (2016) Microclimate and human comfort considerations in planning a historic urban quarter. International Journal of Sustainable Built Environment 5(1):156-167. DOI: https://doi.org/10.1016/j.ijsbe.2016.03.003

Shen D, Zhu N (2015) Influence of the temperature and relative humidity on human heat acclimatization during training in extre mely hot environ ments. Building and Environment 94(1):1-11. DOI: https://doi.org/10.1016/j.buildenv.2015.07.023

Sneyers R (1975) Sur L' analyse statistique des séries d' observations. Genève, Organization Météorologique Mondial. 192p. 
Thom EC (1958) Cooling degree: day air conditioning, heating, and ventilating. Transactions of the ASHRAE 55(1):65-72.

Thom EC (1959) The discomfort index. Weatherwise 12(1):57-60.

Tian Q, Prange M, Merkel U (2016) Precipitation and temperature changes in the major Chinese river basins during 1957-2013 and links to sea surface temperature. Journal of Hydrology 536(1):208-221. DOI: https ://doi.org/10.1016/j.jhydrol.2016.02.048

Tonietto J, Vianello RL, Reg ina MA (2006)

Caracterização macroc limática e potencial enológico de diferentes regiões com vocação vitícola de Minas Gerais . Informe Agropecuário 27(234):32-55.

Van Hove LWA, Jacobs CMJ, Heusinkveld BG Elbers JA, Van Driel BL, Holtslag AAM (2015) Temporal and spatial variability of urban heat is land and thermal comfort within the Rotterdam agglo meration. Building and Environ ment 83(1):91-103. DOI:

https://doi.org/10.1016/j.buildenv.2014.08.029
Vaneckova P, Bambrick H (2013) Cause-s pecific hospital admissions on hot days in Sydney, Australia. PLoS ONE 8(1):1-9. DOI:

https://doi.org/10.1371/journal.pone.0055459

Vianello RL, Alves, AR (2012) Meteorologia básica e aplicações. Viçosa, Universidade Federal de Viçosa, 2 ed. 460p.

Zhang Y, Zhang J, Chen H, Du X, Meng Q (2014) Effects of step changes of temperature and humidity on human responses of people in hot-humid area of China. Building and Environ ment 80(1):174-183. DOI:

https://doi.org/10.1016/j.buildenv.2014.05.023

Zheng G, Zhu N, Tian Z, Chen Y, Sun B (2012)

Application of a trape zoidal fuzzy AHP method for work safety evaluation and early warning rating of hot and humid environ ments. Safety Science 50(2):228-239. DOI: https ://doi.org/10.1016/j.s sci.2011.08.042 